Економічні науки: збірник наукових праць Луцького національного технічного університету. - Серія "Регіональна економіка". - Випуск 15 (59). - Редкол.: відп. ред. д.е.н., професор Л.Л. Ковальська. - Луцьк: ІВВ Луцького НТУ, 2018. - 292 с.

УДК 657:338.48

Лепкий М.I., к.г.н., доц.

Луцький національний технічний університет

\title{
ЕКОНОМІЧНИЙ АНАЛІЗ ДІЯЛЬНОСТІ СУБ ЄКТІВ ТУРИСТИЧНОЇ ДІЯЛЬНОСТІ В ЗАХІДНОМУ РЕГІОНІ УКРАїНИ
}

У статті дано характеристику стану регіонального ринку туристичного продукту, проаналізовано динаміку кількості суб' єктів туристичної діяльності. На основі аналізу статистичних даних виявлено нерівномірність розташування туристичних операторів, туристичних агентів, які здійснюють туристичне обслуговування в Західному регіоні України.

Ключові слова: туризм, регіон, аналіз, туристична діяльність, туристичний продукт.

\section{Lepkiy M.}

\section{THE ECONOMIC ANALYSIS OF ACTIVITIES OF THE TOURISM SPHERE SUBJECTS IN THE WESTERN REGION OF UKRAINE}

The western region of Ukraine is usually viewed as a region with a high level of agriculture, industry, education, and science. Tourism is not crucial in the development of the region, although there are favorable natural, historical-cultural, economic, socio-demographic conditions for it.

The aim of this article is to analyse indicators and identify features of tourism development in the western region of Ukraine.

The western region of Ukraine is a place where significant recreational and tourist potential is concentrated. The percentage share of this potential constitutes $22.8 \%$ out of the total natural resource potential of Ukraine, $77 \%$ are standing for recreation and tourism resources and $23 \%$ for the resources of sanatorium and spa treatment. A significant proportion of nature-recreational potential in the western region is found in the Transcarpathian, Lviv, Ivano-Frankivsk regions, and has a smaller proportion - Chernivtsi, Volyn, Rivne and Ternopil regions. Tourism activity in the Western region of Ukraine is carried out by tourism enterprises, sanatorium and health resorts, hotels and other places for short-term residence. As of 01.01 .18 , according to reports, there are 686 subjects of tourism activity in the western region. Most of them are situated in regional centers. Among the regions, the largest number of tourism enterprises is in Lviv and Ivano-Frankivsk regions. The analysis of the dynamics of the number of tourist enterprises in 2011-2017 
Економічні науки: збірник наукових праць Луцького національного технічного університету. - Серія "Регіональна економіка". - Випуск 15 (59). - Редкол.: відп. ред. д.е.н., професор Л.Л. Ковальська. - Луиьк: ІВВ Луиького НТУ, 2018. - 292 с.

shows that their number has significantly decreased due to events occurring on the territory of Ukraine.

The decrease in the number of tourists visiting the west region in recent years has happened due to the low level of development of recreation and tourism infrastructure, insufficient quality of tourism product for various target groups of tourists, lack of hotel facilities in accordance with world standards, inconsistency of quality of services in the service of international level standards, insufficient transport links in some areas. By means of dealing with these factors, we can contribute to the significant development of tourism in the western region of Ukraine and stimulate the related industries of the country's economy.

Key words: tourism, region, analysis, tourism activity, tourism product.

\section{Лепкий М.И.}

\section{ЭКОНОМИЧЕСКИЙ АНАЛИЗ ДЕЯТЕЛЬНОСТИ СУБЪЕКТОВ ТУРИСТИЧЕСКОЙ ДЕЯТЕЛЬНОСТИ В ЗАПАДНОМ РЕГИОНЕ УКРАИНЫ}

В статье дана характеристика состояния регионального рынка туристического продукта, проанализирована динамика количества субъектов туристической деятельности. На основе анализа статистических данных выявлено неравномерность расположения туристических операторов, туристических агентов, осуществляющих туристическое обслуживание в Западном регионе Украины.

Ключевые слова: туризм, регион, анализ, туристическая деятельность, туристический продукт.

Постановка проблеми у загальному вигляді та ії зв'язок з важливими науковими і практичними завданнями. Туризм відіграє важливу роль у регіональному розвитку. Нині більшість наукових досліджень спрямовано на аналіз економічних аспектів його розвитку, що зазвичай пов'язується iз зовнішнім туризмом. При цьому недостатньо уваги приділяється вивченню аспектів внутрішнього туризму, який може стати важливим інструментом відродження української економіки [4]. Західний регіон України вважається регіоном 3 високим рівнем розвитку сільського господарства, промисловості, освіти і науки. Туризм не є визначальним у розвитку регіону, хоча має для цього сприятливі передумови природні, історико-культурні, економічні, соціально- 
Економічні науки: збірник наукових праць Луцького національного технічного університету. - Серія "Регіональна економіка". - Випуск 15 (59). - Редкол.: відп. ред. д.е.н., професор Л.Л. Ковальська. - Луцьк: ІВВ Луцького НТУ, 2018. - 292 с.

демографічні. Втім, проблеми організації обліку та аналізу основних господарських операцій суб'єктів туристичної діяльності потребують подальшого наукового опрацювання.

Аналіз останніх досліджень, у яких започатковано вирішення проблеми. Дослідження туризму як важливого соціоекономічного явища i процесу має місце у працях вітчизняних вчених, серед яких О. Бобарикіна, Л. Дядечко, В. Кифяк, О. Любіцева, С. Нездоймінов, Т. Ткаченко та ін. Наукові підходи щодо аналізу туристичного бізнесу та його особливостей розвитку окремого регіону сьогодні вибірково досліджені.

Цілі статті. Метою даної статті є аналіз показників та виявлення особливостей розвитку туризму в Західному регіоні України.

Виклад основного матеріалу дослідження 3 обгрунтуванням отриманих наукових результатів. Західний регіон України $є$ територією, де зосереджений значний рекреаційно-туристичний потенціал. Питома частка останнього у сумарному природно-ресурсному потенціалі України складає 22,8 \% від загальнодержавного показника, у тому числі $77 \%$ припадає на ресурси відпочинку і туризму і $23 \%$ - на ресурси санаторно-курортного лікування. У територіальному розрізі Західного регіону (табл. 1) значна частка природнорекреаційного потенціалу припадає на Закарпатську $(7,3 \%)$, Львівську $(5,6 \%)$, Івано-Франківську $(4,1 \%)$ області, дещо менше має - Чернівецька $(1,8 \%)$, Волинська $(1,6 \%)$, Рівненська $(1,2 \%)$ та Тернопільська $(1,2 \%)$ області [2]. 
Економічні науки: збірник наукових праць Луцького національного технічного університету. - Серія "Регіональна економіка". - Випуск 15 (59). - Редкол.: відп. ред. д.е.н., професор Л.Л. Ковальська. - Луцьк: ІВВ Луиького НТУ, 2018. - 292 с.

Таблиця 1

Природно-рекреаційний потенціал Західного регіону [2]

\begin{tabular}{|c|c|c|c|c|c|}
\hline \multirow{3}{*}{$\begin{array}{c}\text { Адміністра- } \\
\text { тивна } \\
\text { одиниця }\end{array}$} & \multirow{3}{*}{$\begin{array}{c}\text { Природно- } \\
\text { рекреа- } \\
\text { ційний } \\
\text { потенціал, } \\
\text { тис. га }\end{array}$} & \multirow{3}{*}{$\begin{array}{c}\text { Природно- } \\
\text { рекреацій- } \\
\text { ний } \\
\text { потенціал, } \\
\text { млн. грн. }\end{array}$} & \multicolumn{3}{|c|}{$\begin{array}{c}\text { Природно-рекреаційний } \\
\text { потенціал }\end{array}$} \\
\hline & & & \multirow{2}{*}{$\begin{array}{c}\text { питома } \\
\text { частка, } \\
\%\end{array}$} & \multicolumn{2}{|c|}{ у тому числі, \% } \\
\hline & & & & $\begin{array}{l}\text { ресурсів } \\
\text { відпо- } \\
\text { чинку і } \\
\text { туризму }\end{array}$ & $\begin{array}{c}\text { ресурсів } \\
\text { санатор- } \\
\text { но-курор- } \\
\text { тного } \\
\text { лікування }\end{array}$ \\
\hline Волинська & 224,0 & 84,0 & 1,6 & 80 & 20 \\
\hline Закарпатська & 425,9 & 379,6 & 7,3 & 57 & 43 \\
\hline $\begin{array}{c}\text { Івано- } \\
\text { Франківська } \\
\end{array}$ & 183,8 & 212,0 & 4,1 & 84 & 16 \\
\hline Львівська & 339,8 & 290,1 & 5,6 & 70 & 30 \\
\hline Рівненська & 111,0 & 63,2 & 1,2 & 80 & 20 \\
\hline Тернопільська & 96,6 & 61,3 & 1,2 & 79 & 21 \\
\hline Чернівецька & 64,0 & 94,1 & 1,8 & 79 & 21 \\
\hline $\begin{array}{c}\text { Західний } \\
\text { регіон }\end{array}$ & 1445,1 & 1184,3 & 22,8 & 77 & 23 \\
\hline Україна & 3507,1 & 5201,4 & 100 & 75 & 25 \\
\hline
\end{tabular}

Рекреаційно-туристичний потенціал Західного регіону України на 91,06\% складається 3 природних рекреаційних ресурсів у сумарному природно-ресурсному потенціалі України, що значно вище відповідного показника по Україні $(9,64 \%)$ (табл. 2).

Таблиця 2

Компонентна структура природно-ресурсного потенціалу областей Західного регіону України [2]

\begin{tabular}{|c|c|c|c|c|c|c|}
\hline \multirow{2}{*}{$\begin{array}{c}\text { Адміністративна } \\
\text { одиниця }\end{array}$} & \multicolumn{6}{|c|}{ Питома вага ресурсу в природно-ресурсному } \\
\cline { 2 - 7 } & $\begin{array}{c}\text { Пінера- } \\
\text { льні }\end{array}$ & Водні & Земельні & Лісові & $\begin{array}{c}\text { Фауніс- } \\
\text { тичні }\end{array}$ & $\begin{array}{c}\text { Рекре- } \\
\text { аційні }\end{array}$ \\
\hline Волинська & 0,95 & 18,02 & 55,18 & 16,24 & 0,41 & 9,20 \\
\hline Закарпатська & 3,06 & 31,48 & 19,36 & 17,44 & 0,08 & 28,58 \\
\hline
\end{tabular}


Економічні науки: збірник наукових праць Луцького національного технічного університету. - Серія "Регіональна економіка". - Випуск 15 (59). - Редкол.: відп. ред. д.е.н., професор Л.Л. Ковальська. - Луцьк: ІВВ Луцького НТУ, 2018. - 292 с.

\begin{tabular}{|c|c|c|c|c|c|c|}
\hline $\begin{array}{c}\text { Івано- } \\
\text { Франківська }\end{array}$ & 7,41 & 33,31 & 24,13 & 17,62 & 0,13 & 17,40 \\
\hline Львівська & 22,55 & 22,68 & 29,24 & 11,07 & 0,18 & 14,28 \\
\hline Рівненська & 5,00 & 16,45 & 55,01 & 16,14 & 0,75 & 6,65 \\
\hline Тернопільська & 1,24 & 13,59 & 74,97 & 4,66 & 0,15 & 5,40 \\
\hline Чернівецька & 10,77 & 12,89 & 59,13 & 6,70 & 0,96 & 9,55 \\
\hline Україна & 28,26 & 13,08 & 44,38 & 4,17 & 0,47 & 9,64 \\
\hline
\end{tabular}

Туристичну діяльність в Західному регіоні України проводять туристичні підприємства, санаторно-курортні і оздоровчі заклади, готелі та інші місця для короткотермінового проживання. Для характеристики туристичної діяльності в регіоні дослідження було проаналізовано статистичну звітність Державної служби статистики України. Станом на 1.01 .18 р., згідно звітності, в Західному регіоні України нараховується 686 суб’єктів туристичної діяльності (табл. 3).

Таблиця 3

Кількість суб'єктів туристичної діяльності в Західному регіоні України в 2017 році [6]*

\begin{tabular}{|l|c|}
\hline \multicolumn{1}{|c|}{ Область } & $\begin{array}{c}\text { Кількість суб'єктів туристичної } \\
\text { діяльності (од.) }\end{array}$ \\
\hline Волинська & 66 \\
\hline Закарпатська & 63 \\
\hline Івано-Франківська & 105 \\
\hline Львівська & 282 \\
\hline Рівненська & 60 \\
\hline Тернопільська & 45 \\
\hline Чернівецька & 65 \\
\hline Західний регіон & 686 \\
\hline Україна & 3469 \\
\hline
\end{tabular}

У загальній кількості враховані юридичні особи та фізичні особипідприємці

Більшість 3 них функціонують в обласних центрах. Серед областей найбільше туристичних підприємств припадає на Львівську (282) та Івано-Франківську (105) області. Аналіз динаміки кількості туристичних підприємств 2011 - 2017 рp. 
Економічні науки: збірник наукових праць Луцького національного технічного університету. - Серія "Регіональна економіка". - Випуск 15 (59). - Редкол.: відп. ред. д.е.н., професор Л.Л. Ковальська. - Луцьк: ІВВ Луиького НТУ, 2018. - 292 с.

свідчить про їх значне скорочення у зв'язку з подіями, що відбуваються на території України (рис.1, табл. 4). Так, якщо у 2011 році їх налічувалось 812, то у 2017 - 686 (зменшення у 1,2 рази).

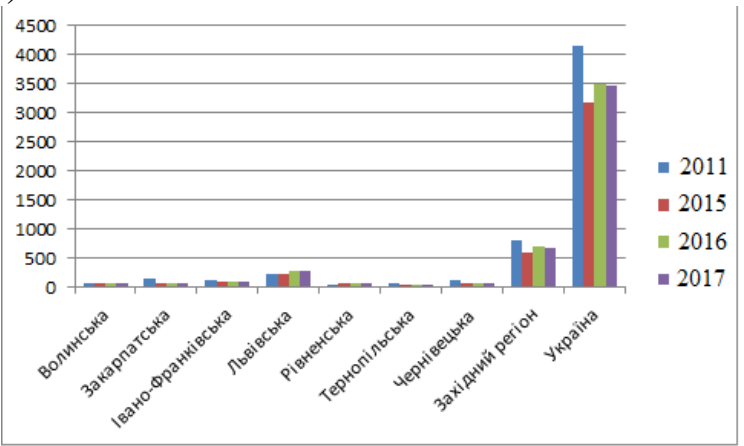

Області Західного регіону України

Рис.1. Динаміка кількості суб'єктів підприємницької діяльності у сфері туризму в Західному регіоні України (побудовано автором)

Таблиця 4

Кількість суб'єктів туристичної діяльності в Західному регіоні України [6]*

\begin{tabular}{|l|c|c|c|c|}
\hline \multirow{2}{*}{ Область } & \multicolumn{4}{|c|}{ Кількість суб'єктів туристичної діяльності (од.) } \\
\cline { 2 - 5 } & 2011 & 2015 & 2016 & 2017 \\
\hline Волинська & 76 & 68 & 69 & 66 \\
\hline Закарпатська & 149 & 67 & 65 & 63 \\
\hline Івано-Франківська & 116 & 83 & 107 & 105 \\
\hline Львівська & 230 & 221 & 272 & 282 \\
\hline Рівненська & 50 & 59 & 66 & 60 \\
\hline Тернопільська & 72 & 43 & 53 & 45 \\
\hline Чернівецька & 119 & 65 & 66 & 65 \\
\hline Західний регіон & 812 & 606 & 698 & 686 \\
\hline Україна & 4157 & 3182 & 3506 & 3469 \\
\hline
\end{tabular}

У загальній кількості враховані юридичні особи та фізичні особи-підприємці

Динаміку кількості туристів в Західному регіоні за період 2015-2017 pр. наведено в табл. 5, яка свідчить про зменшення 
Економічні науки: збірник наукових праць Луцького національного технічного університету. - Серія "Регіональна економіка". - Випуск 15 (59). - Редкол.: відп. ред. д.е.н., професор Л.Л. Ковальська. - Луиьк: ІВВ Луиького НТУ, 2018. - 292 с.

кількості туристів, що були обслуговувані суб'єктами туристичної діяльності в 2017 році.

Таблиця 5

Кількість туристів, обслугованих туроператорами та турагентами в Західному регіоні України [6]*

\begin{tabular}{|l|c|c|c|c|}
\hline \multirow{2}{*}{ Область } & \multicolumn{4}{|c|}{ Кількість туристів (од.) } \\
\cline { 2 - 5 } & 2011 & 2015 & 2016 & 2017 \\
\hline Волинська & 14657 & 15620 & 26526 & 17047 \\
\hline Закарпатська & 21773 & 10656 & 11601 & 14652 \\
\hline $\begin{array}{l}\text { Івано- } \\
\text { Франківська }\end{array}$ & 59327 & 65885 & 79973 & 73309 \\
\hline Львівська & 128709 & 112472 & 181827 & 175150 \\
\hline Рівненська & 9490 & 6640 & 9022 & 11168 \\
\hline Тернопільська & 14164 & 6668 & 7536 & 9558 \\
\hline Чернівецька & 36116 & 15662 & 19415 & 20341 \\
\hline Західний регіон & 284236 & 233603 & 335900 & 321225 \\
\hline Україна & 1840483 & 2019576 & 2549606 & 2806426 \\
\hline
\end{tabular}

У загальній кількості враховані юридичні особи та фізичні особипідприємці

На туристичний попит у регіоні впливає ряд факторів, один 3 яких - туристична інфраструктура. До неї відносяться готелі, туристичні фірми, сервісні центри, інформація, державні установи, транспорт, фінанси, страхові фірми та інші інститути, які сприяють розвитку туризму. Зменшення кількості туристів, що відвідали Західний регіон за останні роки, вражає, і така ситуація зумовлена низьким рівнем розвитку рекреаційнотуристичної інфраструктури, недостатньо якісними $\epsilon$ туристичні продукти для різних цільових груп туристів, браком об'єктів готельного господарства відповідно до світових стандартів, невідповідністю якості послуг у сфері обслуговування рівню міжнародних стандартів, недостатнім транспортним сполученням в деяких областях. Подолання даних факторів сприятиме значному розвитку туристичної діяльності в Західному регіоні України та стимулюватиме пов’ язані галузі економіки країни. 
Економічні науки: збірник наукових праць Луцького національного технічного університету. - Серія "Регіональна економіка". - Випуск 15 (59). - Редкол.: відп. ред. д.е.н., професор Л.Л. Ковальська. - Луцьк: ІВВ Луичького НТУ, 2018. - 292 с.

Висновки. Розвиток туристичного бізнесу в Західному регіоні України дає підстави стверджувати, що основним напрямком діяльності переважної більшості туристичних операторів регіону $є$ виїзний туризм. Сьогодні в умовах євроінтеграційних та глобалізаційних процесів перед суб'єктами туристичного бізнесу постає завдання поширення в 'ізного та внутрішнього туризму. Варто також зазначити, що негативна військово-політична ситуація в країні стимулює в більшій мірі звертати увагу на розвиток та популяризацію внутрішнього туризму. Усі ці внутрішні і зовнішні фактори повинні змусити туристичних операторів переглянути основні напрямки своєї діяльності. Для того, щоб окреслити правильний шлях діяльності, туристичним операторам необхідно покращати рівень надання туристичних послуг, знайти внутрішні ресурси для інвестування у туристичний бізнес.

1. Бігус М.М. Аналіз сучасного стану туристичного бізнесу Львівщини у контексті глобалізаційних процесів / М.М. Бігус // Науковий вісник Міжнародного гуманітарного університету. Серія «Економіка і менеджмент», 2015. - Випуск 14. - С. 124-128.

2. Матвійчук Л.Ю. Механізми створення геоінформаційної системи туристично-рекреаційних ресурсів: монографія / Л.Ю. Матвійчук, М.I. Лепкий, О.М. Лютак, І.В. Тищук - Луцьк: IBВ Луцького НТУ, 2016. $196 \mathrm{c}$.

3. Нездоймінов С.Г. Підприємницький вектор розвитку регіонального туризму: монографія / С.Г. Нездоймінов. - Одеса: Пальміра, 2011. - 344 с.

4. Прокопішина О.В. Облік та аналіз виробництва туристичного продукту / О.В. Прокопішина // Бізнес Інформ: наук. журн. - Харків, 2014. № 5. - C. 210-215.

5. Скриль I. Сучасні тенденції розвитку туризму в Харківському регіоні/ I. Скриль // Часопис соціально-економічної географії: Міжрегіональний збірник наукових праць. - Харків: Харківський національний університет імені В.Н. Каразіна, 2012. - Вип. 13 (2). - С. 128-131.

6. Туристична діяльність в Україні у 2017 році. Статистичний збірник. - К.: Державна служба статистики України, 2018. - 90 с. 